\title{
Contribution of dust inputs to dissolved organic carbon and water transparency in Mediterranean reservoirs
}

\author{
I. de Vicente ${ }^{1,2}$, E. Ortega-Retuerta ${ }^{1,2, *}$, R. Morales-Baquero ${ }^{1,2}$, and I. Reche ${ }^{1,2}$ \\ ${ }^{1}$ Departamento de Ecología, Facultad de Ciencias, Universidad de Granada, 18071, Granada, Spain \\ ${ }^{2}$ Instituto del Agua, Universidad de Granada, 18071 Granada, Spain \\ *current address: Institut de Ciències del Mar-CSIC, 08003 Barcelona, Spain
}

Correspondence to: I. Reche (ireche@ugr.es)

Received: 19 May 2012 - Published in Biogeosciences Discuss.: 11 July 2012

Revised: 18 November 2012 - Accepted: 19 November 2012 - Published: 10 December 2012

\begin{abstract}
The Mediterranean reservoirs receive frequent atmospheric Saharan dust inputs with soil-derived organic components mostly during the stratification periods, when run-off inputs are particularly limited. Here, we quantified and optically characterized the water-soluble organic carbon (WSOC) of the (dry and wet) atmospheric deposition in collectors placed near three reservoirs from the western Mediterranean Basin. In addition, we determined the WSOC contribution to the pool of dissolved organic carbon (DOC) in the reservoirs and the influence of dust-derived chromophoric organic components on the water transparency during their stratification periods.

We found synchronous dynamics in the WSOC atmospheric inputs among the three collectors and in the DOC concentrations among the three reservoirs. The DOC concentrations and the WSOC atmospheric inputs were positive and significantly correlated in the most oligotrophic reservoir (Quéntar) and in the reservoir with the highest ratio of surface area to mixing water depth (Cubillas). Despite these correlations, WSOC atmospheric inputs represented less than $10 \%$ of the total DOC pool, suggesting that indirect effects of dust inputs on reservoir DOC may also promote these synchronous patterns observed in the reservoirs. Chromophoric components from dust inputs can significantly reduce the water transparency to the ultraviolet radiation (UVR). The depths where UVR at $\lambda=320 \mathrm{~nm}$ was reduced to ten percent of surface intensity $\left(Z_{10} \%\right)$ decreased $27 \mathrm{~cm}$ in Béznar, $49 \mathrm{~cm}$ in Cubillas, and $69 \mathrm{~cm}$ in Quéntar due to the dust inputs. Therefore, the increasing dust export to the atmosphere may have consequences for the water transparency of aquatic ecosystems located under the influence of the global dust belt.
\end{abstract}

\section{Introduction}

The largest and most persistent dust sources in the world are located in the Northern Hemisphere, mainly in the "dust belt" that extends from the west coast of North Africa, over the Middle East, Central and South Asia, to China (Prospero et al., 2002). The Sahara Desert accounts for about $50 \%$ of the global dust production (Schütz et al., 1981). This dust export to the atmosphere has increased exponentially in the last decades and centuries as a consequence of North Africa droughts (Prospero and Lamb, 2003), the human-induced desertification (Moulin and Chiapello, 2006) and the onset of the commercial agriculture in the Sahel region (Mulitza et al., 2010). These massive airborne plumes from the Sahara Desert travel toward the Atlantic Ocean by the predominant northeasterly trades and to the Mediterranean region under the presence of cyclones frequent particularly during spring and summer (Moulin et al., 1997). Therefore, Mediterranean aquatic ecosystems are intensely exposed to atmospheric inputs of Saharan dust (Löye-Pilot et al., 1986; Bergametti et al., 1992).

Previous studies in several aquatic ecosystems of the Mediterranean region showed that the Saharan dust contains inorganic nutrients, such as soluble phosphorus, that stimulate both phytoplankton (Bonnet et al., 2005; MoralesBaquero et al., 2006; Pulido-Villena et al., 2008a) and bacterioplankton (Pulido-Villena et al., 2008b; Reche et al., 2009). More recently, Mladenov et al. $(2009,2011)$ determined that the organic carbon associated with the atmospheric dust can contribute significantly to the dissolved organic carbon (DOC) pool in alpine lakes, and that a fraction of this water-soluble organic carbon (WSOC) from the dust

Published by Copernicus Publications on behalf of the European Geosciences Union. 
contains chromophoric groups similar to humic substances that can be traced in the lakes.

Recently, the role of the DOC in inland waters is being revaluated in the context of the global $\mathrm{C}$ cycle, since rivers, lakes and reservoirs are active sites for transport, transformation and storage of considerable amounts of terrestrial organic C (Cole et al., 2007; Tranvik et al., 2009). A portion of this DOC absorbs ultraviolet and visible radiation and is termed chromophoric dissolved organic matter (CDOM). CDOM is a key parameter regulating the intensity of ultraviolet radiation in the water column (Morris et al., 1995).

DOC and CDOM dynamics in aquatic ecosystems depend on the relative influence of their inherent properties such as the morphometry, photosynthetic productivity, or microbial $\mathrm{C}$ processing, as well as external factors such as the catchment area, the soil type, or the environmental conditions that determine the allochthonous $\mathrm{C}$ inputs (Tipping et al., 1988; Curtis, 1998; Reche et al., 2000; Pace and Cole, 2002; Reche and Pace, 2002; Mladenov et al., 2008). Although the external factors controlling DOC in lakes are well documented in diverse geographical regions (Xenopoulos et al., 2003; Sobek et al., 2007), scarce information exists for the reservoirs, which assume a major role of the run-off inputs. However, more information is needed in view of the increasing area occupied by reservoirs worldwide, particularly in arid and semiarid regions where run-off is very limited. In fact, Downing et al. (2006) recognized that the volume of water in impoundments increased by an order of magnitude between the 1950 s and the present.

The objectives of this work were, first, to determine if the atmospheric water-soluble organic carbon (WSOC) and its chromophoric content can affect directly the DOC pool and the water UVR transparency in three well-contrasting reservoirs from the Mediterranean basin and, second, to assess if the Saharan dust exports can be considered as a climatic factor controlling DOC and CDOM in reservoirs. The selected reservoirs clearly differed in their trophic conditions, morphometries and watershed characteristics (Perez-Martínez et al., 1991; Morales-Baquero et al., 1994; de Vicente et al., 2008) to explore the relative importance of the reservoirinherent properties in its responsiveness to atmospheric dust deposition.

\section{Material and methods}

\subsection{Study sites}

We selected three reservoirs that were approximately $40 \mathrm{~km}$ apart and located inside an area submitted to intense dust deposition in Southern Spain (Mladenov et al., 2011). The study reservoirs present contrasting characteristics, particularly with respect to nutrient limitation, morphometry and catchment properties (Table 1). Quéntar is an oligotrophic, extremely $P$-limited $(N: P$ molar ratio $=381)$ reservoir. It is
Table 1. Location and general physical, chemical and biological features of the study reservoirs. $Z_{\mathrm{mix}}$ is the mixing water depth $(6 \mathrm{~m}$ in Cubillas and $15 \mathrm{~m}$ in Quéntar and Béznar). Modified from de Vicente et al. (2008).

\begin{tabular}{|c|c|c|c|}
\hline Reservoirs & Quéntar & Cubillas & Béznar \\
\hline Coordinates & $\begin{array}{l}37^{\circ} 12^{\prime} 11^{\prime \prime} \mathrm{N}, \\
3^{\circ} 26^{\prime} 17^{\prime \prime} \mathrm{W}\end{array}$ & $\begin{array}{l}37^{\circ} 16^{\prime} 29^{\prime \prime} \mathrm{N} \\
3^{\circ} 40^{\prime} 59^{\prime \prime} \mathrm{W}\end{array}$ & $\begin{array}{l}36^{\circ} 54^{\prime} 54^{\prime \prime} \mathrm{N}, \\
3^{\circ} 32^{\prime} 25^{\prime \prime} \mathrm{W}\end{array}$ \\
\hline Year of impoudment & 1973 & 1958 & 1986 \\
\hline Altitude a.s.l. (m) & 1030 & 650 & 485 \\
\hline $\begin{array}{l}\text { Total Volume } \\
\left(V ; 10^{6} \mathrm{~m}^{3}\right)\end{array}$ & 13.6 & 21 & 54 \\
\hline $\begin{array}{l}\text { Reservoir area } \\
\left(A_{\mathrm{R}} ; \mathrm{km}^{2}\right)\end{array}$ & 0.42 & 2 & 1.7 \\
\hline $\begin{array}{l}\text { Catchment area } \\
\left(A_{\mathrm{C}} ; \mathrm{km}^{2}\right)\end{array}$ & 101 & 626 & 352 \\
\hline$A_{\mathrm{C}}: A_{\mathrm{R}}$ & 240 & 313 & 207 \\
\hline $\begin{array}{l}\text { Water retention } \\
\text { time }(y)\end{array}$ & 3.85 & 2.94 & 1.00 \\
\hline $\begin{array}{l}A_{\mathrm{R}}: z_{\operatorname{mix}} \\
\left(10^{3} \mathrm{~m}\right)\end{array}$ & 28 & 333 & 113 \\
\hline $\begin{array}{l}\text { Conductivity } \\
\left(\mu \mathrm{S} \mathrm{cm}^{-1}\right)\end{array}$ & 319 & 646 & 435 \\
\hline $\begin{array}{l}\text { Total phosphorus } \\
(\mu \mathrm{mol} \mathrm{L}-1)^{\mathrm{a}}\end{array}$ & $\begin{array}{l}0.12 \\
(0.03-0.28)\end{array}$ & $\begin{array}{l}0.84 \\
(0.26-1.47)\end{array}$ & $\begin{array}{l}1.05 \\
(0.38-1.70)\end{array}$ \\
\hline $\begin{array}{l}\text { Total nitrogen } \\
\left(\mu \mathrm{mol} \mathrm{L}{ }^{-1}\right)^{\mathrm{a}}\end{array}$ & $\begin{array}{l}40.0 \\
(12.9-94.3)\end{array}$ & $\begin{array}{l}185.0 \\
(18.6-350.0)\end{array}$ & $\begin{array}{l}82.9 \\
(27.1-305.7)\end{array}$ \\
\hline$N: P$ molar ratio ${ }^{\mathrm{a}}$ & 333 & 220 & 79 \\
\hline $\begin{array}{l}\text { Chlorophyll } a \\
\left(\mu \mathrm{g} \mathrm{L}^{-1}\right)\end{array}$ & $\begin{array}{l}2.4 \\
(0.9-6.9)\end{array}$ & $\begin{array}{l}33.1 \\
(10.3-88.5)^{b}\end{array}$ & $\begin{array}{l}40.4 \\
(22.6-73.6)\end{array}$ \\
\hline
\end{tabular}

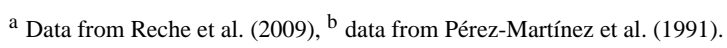

located in the headwaters of the Genil River, a tributary of the Guadalquivir River, the largest river in Southern Spain. Its oligotrophic status is mainly a consequence of its location on a sparsely populated and mountainous area, across closed valley areas that render a low surface: depth ratio (Fig. 1). Cubillas reservoir is also located in the headwaters of the Genil River, but its catchment area is much higher and affected by anthropogenic activity. Béznar reservoir is located at the Izbor River, discharging directly into the Mediterranean Sea. Béznar and Cubillas, in contrast to Quéntar reservoir, are located in open valley areas with a moderate urban development, which are responsible for their higher trophic statuses (Perez-Martinez et al., 1991; Morales-Baquero et al., 1994). The catchment area in Cubillas is more than 6 fold higher than in Quéntar and $\approx 1.8$ fold higher than in Béznar (Table 1). In addition, the reservoir area to maximum depth ratio is much higher in Cubillas (109 m) than in Quéntar $(5 \mathrm{~m})$ and Béznar $(16 \mathrm{~m})$ reservoirs. More details on these reservoirs 


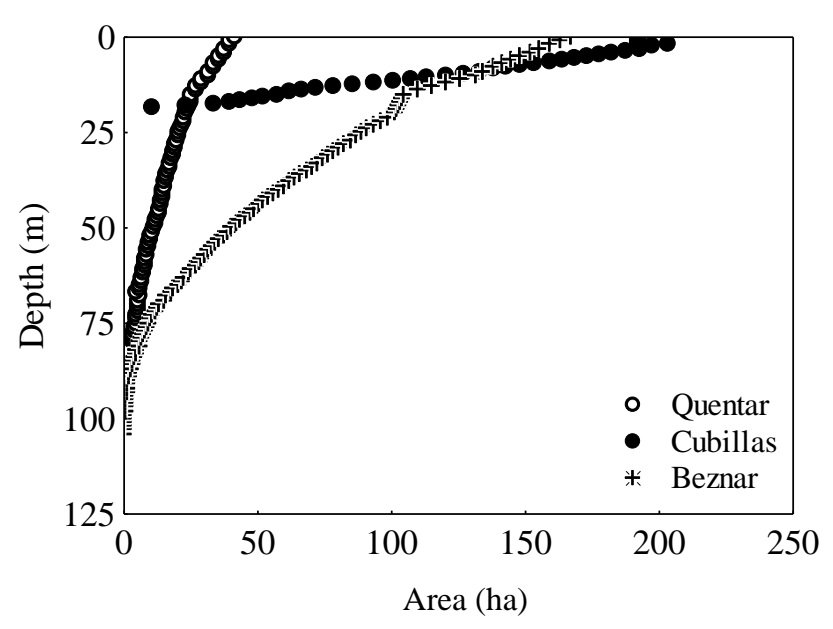

Fig. 1. Absolute hypsographic curves of area versus depth for the three study reservoirs.

can be found elsewhere (Rueda et al., 2007; de Vicente et al., 2008).

During the stratification periods (March-September) in these Mediterranean reservoirs, the typical reduction in rainfall (i.e. the decrease of runoff inputs), the concurrent higher frequency of Sahara dust events, and the conformation of an isolated upper layer (epilimnion) make this period the most convenient for evaluating the maximum contribution of atmospheric organic $\mathrm{C}$ inputs to these reservoirs.

\subsection{Atmospheric deposition sampling}

To obtain the atmospheric samples, we used three passive MTX ARS 1010 automatic deposition samplers located near to each one of the study reservoirs. These passive samplers discriminate between dry and wet atmospheric deposition using a humidity sensor that activates an aluminum lid to cover/uncover the buckets. The samples are collected by sedimentation (dry deposition) or by the rain washout (wet deposition) in separate buckets. The dry deposition was collected by rinsing the bucket with $1000 \mathrm{~mL}$ of Milli-Q ultrapure water. In the wet deposition bucket, the volume of rain was recorded and a $1000 \mathrm{~mL}$ aliquot was analyzed. If the rain volume was $<1000 \mathrm{~mL}$, it was brought up to that volume with Milli-Q ultrapure water. Dry and wet deposition buckets were collected every week during the stratification periods (March-September) of 2004 and 2005.

Water-soluble organic carbon (WSOC) refers to the organic $\mathrm{C}$ from atmospheric deposition that is soluble in water and is measured as DOC (Yang et al., 2003; Mladenov et al., 2008). The concentrations of WSOC $\left(\mathrm{mmol} \mathrm{m}^{-2} \mathrm{~d}^{-1}\right)$ in the dry and wet deposition collected each week were converted to units of daily deposition using the following equation:

WSOC deposition $\left(\mathrm{mmol} \mathrm{m} \mathrm{m}^{-2} \mathrm{~d}^{-1}\right)=$

$\frac{\text { DOC concentration }(\mathrm{mM})}{A_{\mathrm{b}}\left(\mathrm{m}^{2}\right) \cdot 7 \text { (days) }} F$, where $A_{\mathrm{b}}$ is the bucket area and $F$ is a correction factor for the rain volume; $F$ is equal to 1 for dry deposition samples and when the rain volume is $<1 \mathrm{~L}$, but equal to volume of rain when exceeds of value of $1 \mathrm{~L}$.

Samples for WSOC and absorbance analysis were obtained by filtering the collector samples through precombusted Whatman GF/F glass-fiber filters. From the filtrate we took different subsamples for WSOC and absorbance analysis. Subsamples for WSOC were placed into pre-combusted 20-mL glass ampoules, acidified with hydrochloric acid to a final pH ca. 2 , sealed and stored at $4{ }^{\circ} \mathrm{C}$ until analysis. WSOC subsamples were analyzed as non-purgeable organic carbon using a high-temperature catalytic oxidation using a Shimadzu TOC-5000 (precision $0.01 \mathrm{mM}$ ). The absorbance subsamples were measured during the 2004 samplings. UVVIS absorbance scans $(220-750 \mathrm{~nm})$ were performed in 10$\mathrm{cm}$ path length quartz cuvettes using a PerkinElmer Lambda 40 spectrophotometer connected to a computer equipped with UV-WinLab software (absorbance precision=0.001). The average value at the range $700-750 \mathrm{~nm}$ was used to correct UV absorbance values for scattering. Absorbances at 250, 320 and $440 \mathrm{~nm}$ were expressed as Neperian absorption coefficients $\left(a_{\lambda}, \mathrm{m}^{-1}\right)$, and molar absorption coefficients $\left(\varepsilon_{\lambda}\right.$, $\mathrm{m}^{2} \mathrm{~mol}^{-1}$ ) were calculated by dividing $a_{\lambda}$ by the corresponding DOC concentration in $\mathrm{mmol} \mathrm{L}^{-1}$.

To quantify the relevance of the chromophoric components inputs on the diffuse attenuation coefficients for solar UV radiation in the reservoirs, we first scaled up the absorption coefficients at $\lambda=320 \mathrm{~nm}$ measured in the dry and wet buckets $\left(a_{320_{\mathrm{b}}}\right)$ considering the bucket area $\left(A_{\mathrm{b}}\right)$ vs. reservoir area $\left(A_{\mathrm{r}}\right)$ and normalized by epilimnetic volume $\left(V_{\mathrm{r}}\right)$ to get the $a_{320}$ inputs in the epilimnion reservoir:

Dust $a_{320}$ inputs in epilimnion $\left(\mathrm{m}^{-1} \mathrm{~m}^{-3}\right)=$

$$
\frac{a_{320_{\mathrm{b}}}\left(\mathrm{m}^{-1}\right) \cdot A_{\mathrm{r}}\left(\mathrm{m}^{2}\right)}{A_{\mathrm{b}}\left(\mathrm{m}^{2}\right) \cdot V_{\mathrm{r}}\left(\mathrm{m}^{3}\right)}
$$

Then, using the equations for attenuation coefficients at $\lambda=$ $320 \mathrm{~nm}\left(k_{d 320}\right)$ proposed by Morris et al. (1995) $\left(k_{d 320}=\right.$ $\left.1.51 a_{320}-0.12\right)$ and the Lambert-Beer law $\left(I_{z}=I_{0} e^{-k_{d 320}}\right)$, we estimated the depth $(z)$ where light intensity $(I)$ at $320 \mathrm{~nm}$ is reduced to ten percent of that at the surface $(z 10 \%=$ $\left.\ln 0.1 /-k_{d 320}\right)$. For each sampling day in each reservoir, two $z_{10} \%$ values were calculated. The first value was obtained by using the absorption coefficients at $320 \mathrm{~nm}\left(a_{320}\right)$ measured in the reservoirs (in situ conditions). The second value was obtained by using the estimations of absorption coefficients at $320 \mathrm{~nm}$ considering also the chromophoric dust inputs normalized by the epilimnion volume ( + dust conditions) using Eq. (2).

\subsection{Monitoring of the water column}

Water samples were collected on a weekly basis from March to September of 2004 and 2005 . We evenly merged epilimnetic water from three depths above the thermocline. The 
Table 2. Average values and range (in parentheses) of atmospheric inputs of water-soluble organic carbon (WSOC) in 2004 and 2005 and absorption coefficients at $250 \mathrm{~nm}\left(a_{250}\right), 320 \mathrm{~nm}\left(a_{320}\right)$ and $440 \mathrm{~nm}\left(a_{440}\right)$ in the dry and wet atmospheric collectors placed near the study reservoirs in 2004.

\begin{tabular}{|c|c|c|c|c|c|c|c|c|}
\hline \multirow[b]{2}{*}{ Collectors } & \multicolumn{2}{|c|}{ WSOC $\left(\mathrm{mmol} \mathrm{m}^{-2} \mathrm{~d}^{-1}\right)$} & \multirow{2}{*}{$\begin{array}{c}a_{250} \\
\left(\mathrm{~m}^{-1} \mathrm{~m}^{-2} \mathrm{~d}^{-1}\right)\end{array}$} & \multirow{2}{*}{$\begin{array}{c}a_{320} \\
\left(\mathrm{~m}^{-1} \mathrm{~m}^{-2} \mathrm{~d}^{-1}\right)\end{array}$} & \multirow{2}{*}{$\begin{array}{c}a_{440} \\
\left(\mathrm{~m}^{-1} \mathrm{~m}^{-2} \mathrm{~d}^{-1}\right)\end{array}$} & \multirow{2}{*}{$\begin{array}{c}\varepsilon_{250} \\
\left(\mathrm{~m}^{2} \mathrm{~mol}^{-1}\right)\end{array}$} & \multirow{2}{*}{$\begin{array}{c}\varepsilon_{320} \\
\left(\mathrm{~m}^{2} \mathrm{~mol}^{-1}\right)\end{array}$} & \multirow{2}{*}{$\begin{array}{c}\varepsilon_{440} \\
\left(\mathrm{~m}^{2} \mathrm{~mol}^{-1}\right)\end{array}$} \\
\hline & 2004 & 2005 & & & & & & \\
\hline Dry Quéntar & $\begin{array}{c}0.23 \\
(0.04-0.72)\end{array}$ & $\begin{array}{c}0.36 \\
(0.17-0.66)\end{array}$ & $\begin{array}{c}7.24 \\
(3.29-14.16)\end{array}$ & $\begin{array}{c}2.28 \\
(0.55-5.79)\end{array}$ & $\begin{array}{c}0.76 \\
(0.12-1.81)\end{array}$ & $\begin{array}{c}35.01 \\
(14.08-72.04)\end{array}$ & $\begin{array}{c}10.30 \\
(3.70-25.75)\end{array}$ & $\begin{array}{c}3.42 \\
(1.08-6.15)\end{array}$ \\
\hline Dry Cubillas & $\begin{array}{c}0.33 \\
(0.11-0.68)\end{array}$ & $\begin{array}{c}0.363 \\
(0.10-0.91)\end{array}$ & $\begin{array}{c}9.71 \\
(5.88-18.98)\end{array}$ & $\begin{array}{c}3.09 \\
(0.73-7.20)\end{array}$ & $\begin{array}{c}0.95 \\
(0.55-2.33)\end{array}$ & $\begin{array}{c}32.61 \\
(13.41-69.83)\end{array}$ & $\begin{array}{c}10.27 \\
(2.76-19.77)\end{array}$ & $\begin{array}{c}3.98 \\
(1.05-9.51)\end{array}$ \\
\hline Dry Béznar & $\begin{array}{c}0.39 \\
(0.20-0.71)\end{array}$ & $\begin{array}{c}0.40 \\
(0.17-0.68)\end{array}$ & $\begin{array}{c}9.31 \\
(6.82-14.71)\end{array}$ & $\begin{array}{c}2.41 \\
(0.24-4.03)\end{array}$ & $\begin{array}{c}0.69 \\
(0.20-1.41)\end{array}$ & $\begin{array}{c}31.45 \\
(12.84-64.98)\end{array}$ & $\begin{array}{c}7.99 \\
(0.91-19.09)\end{array}$ & $\begin{array}{c}2.32 \\
(0.58-6.45)\end{array}$ \\
\hline Wet Quéntar & $\begin{array}{c}0.26 \\
(0.06-0.67)\end{array}$ & $\begin{array}{c}0.42 \\
(0.17-1.08)\end{array}$ & $\begin{array}{c}8.13 \\
(2.39-13.09)\end{array}$ & $\begin{array}{c}2.30 \\
(1.03-4.06)\end{array}$ & $\begin{array}{c}0.59 \\
(0.26-1.37)\end{array}$ & $\begin{array}{c}54.07 \\
(22.68-108.67)\end{array}$ & $\begin{array}{c}17.60 \\
(5.81-31.98)\end{array}$ & $\begin{array}{c}5.60 \\
(1.11-11.23)\end{array}$ \\
\hline Wet Cubillas & $\begin{array}{c}0.23 \\
(0.01-0.51)\end{array}$ & $\begin{array}{c}0.30 \\
(0.16-0.40)\end{array}$ & $\begin{array}{c}6.51 \\
(3.26-11.47)\end{array}$ & $\begin{array}{c}1.80 \\
(1.44-3.76)\end{array}$ & $\begin{array}{c}0.57 \\
(0.50-1.07)\end{array}$ & $\begin{array}{c}29.99 \\
(19.53-42.84)\end{array}$ & $\begin{array}{c}10.33 \\
(7.39-18.12)\end{array}$ & $\begin{array}{c}3.19 \\
(2.11-5.91)\end{array}$ \\
\hline Wet Béznar & $\begin{array}{c}0.18 \\
(0.06-0.30)\end{array}$ & $\begin{array}{c}0.29 \\
(0.09-0.49)\end{array}$ & $\begin{array}{c}4.63 \\
(2.42-6.57)\end{array}$ & $\begin{array}{c}1.07 \\
(0.30-2.39)\end{array}$ & $\begin{array}{c}0.38 \\
(0.10-0.91)\end{array}$ & $\begin{array}{c}24.89 \\
(14.56-32.61)\end{array}$ & $\begin{array}{c}5.92 \\
(1.48-12.15)\end{array}$ & $\begin{array}{c}2.92 \\
(1.38-4.60)\end{array}$ \\
\hline
\end{tabular}

thermocline was determined each sampling day by using vertical temperature profiles at the deepest site of Quéntar, Béznar and Cubillas reservoirs. Other routine parameters such as conductivity, $\mathrm{pH}$ and $\mathrm{O}_{2}$ were also recorded. Duplicates were performed in all chemical and biological analyses.

Samples for dissolved organic carbon (DOC) analyses were collected after filtration through pre-combusted Whatman GF/F filters into pre-combusted 20-mL glass ampoules, acidified with hydrochloric acid until $\mathrm{pH}$ ca. 2 , sealed and stored at $4{ }^{\circ} \mathrm{C}$ until analysis. DOC was analyzed following the same procedure described for WSOC. UV/Vis absorbance scans $(220-750 \mathrm{~nm})$ of filtered samples were also performed following the same procedure described above for the atmospheric samples.

\subsection{Statistical analysis}

Statistical analyses were performed using Statistica 6.0 software (StatSoft Inc., 1997) and Excel. For Student's t-test, unless otherwise stated, the significance level was set at $p<0.05$. Since synchronous dynamics of variables among neighbour ecosystems is considered as a sign of climatic forcing at regional scale (Baines et al., 2000), we first performed correlation analyses among the WSOC and DOC dynamics and its optical properties to evaluate if there was any significant reservoir-external forcing. To link the atmospheric deposition of WSOC and DOC in the reservoir waters, we performed correlation analyses.

\section{Results}

\subsection{Water-soluble organic carbon and chromophoric content in dust inputs}

The average dry and wet deposition of WSOC during 2004 was 0.23 and $0.26 \mathrm{mmol} \mathrm{m}^{-2} \mathrm{~d}^{-1}$ in Quéntar; 0.33 and
$0.23 \mathrm{mmol} \mathrm{m} \mathrm{m}^{-2} \mathrm{~d}^{-1}$ in Cubillas; and 0.39 and $0.18 \mathrm{mmol}$ $\mathrm{m}^{-2} \mathrm{~d}^{-1}$ in Béznar (Table 2). During 2005, the average dry and wet deposition of WSOC was 0.36 and $0.42 \mathrm{mmol}$ $\mathrm{m}^{-2} \mathrm{~d}^{-1}$ in Quéntar; 0.36 and $0.30 \mathrm{mmol} \mathrm{m}^{-2} \mathrm{~d}^{-1}$ in $\mathrm{Cu}-$ billas; and 0.40 and $0.29 \mathrm{mmol} \mathrm{m}^{-2} \mathrm{~d}^{-1}$ in Béznar (Table 2). Significant synchrony of atmospheric WSOC inputs among collectors was found when all $(2004+2005)$ data were merged and also between the collectors located near Cubillas and Quéntar reservoirs for each year independently (Fig. 2; Table 3).

In 2004, the average absorption coefficients at $320 \mathrm{~nm}$ $\left(a_{320}\right)$ of dry and wet deposition of WSOC were 2.28 and $2.30 \mathrm{~m}^{-1} \mathrm{~m}^{-2} \mathrm{~d}^{-1}$ in Quéntar; and 3.09 and $1.80 \mathrm{~m}^{-1}$ $\mathrm{m}^{-2} \mathrm{~d}^{-1}$ in Cubillas; and 2.41 and $1.07 \mathrm{~m}^{-1} \mathrm{~m}^{-2} \mathrm{~d}^{-1}$ in Béznar (Table 2). The absorption coefficients at $250 \mathrm{~nm}$ $\left(a_{250}\right)$ and $440 \mathrm{~nm}\left(a_{440}\right)$ of the dry and wet deposition of the WSOC are also reported in Table 2. We also observed synchronous dynamics in the absorption coefficients at $320 \mathrm{~nm}$ $\left(a_{320}\right)$ between the collectors located in Quéntar and in $\mathrm{Cu}-$ billas reservoirs (Fig. 2, Table 3).

The most prominent peaks of WSOC and $a_{320}$ inputs (Fig. 2, black arrows) can be associated with Saharan dust intrusions over Southern Spain as reflected by the aerosol index global maps and the data provided by the Spanish Ministry of Agriculture, Food, and Environment (www.calima.ws) (Fig. 3).

\subsection{Dissolved organic matter and absorption coefficients in the reservoirs}

During the stratification period of 2004, average DOC concentration was $0.16 \mathrm{mM}$ in Quéntar, $0.36 \mathrm{mM}$ in Cubillas and $0.24 \mathrm{mM}$ in Béznar and average DOC concentration during stratification of 2005 was $0.12 \mathrm{mM}$ in Quéntar, $0.34 \mathrm{mM}$ in Cubillas and 0.24 mM in Béznar (Fig. 4, Table 4). DOC concentrations in the three study reservoirs showed synchronous dynamics during 2004 and 2005, except between Quéntar 
Table 3. Correlation coefficients between the different atmospheric collectors for total deposition of water-soluble organic carbon (WSOC) and their absorption coefficients at $320 \mathrm{~nm}\left(a_{320}\right)$.

\begin{tabular}{|c|c|c|c|c|}
\hline & & Collectors at & Quéntar & Cubillas \\
\hline \multirow{3}{*}{ WSOC } & 2004 & $\begin{array}{l}\text { Cubillas } \\
\text { Béznar }\end{array}$ & $\begin{array}{r}0.76^{\mathrm{b}} \\
0.44^{\mathrm{NS}}\end{array}$ & $0.59^{\mathrm{a}}$ \\
\hline & 2005 & $\begin{array}{l}\text { Cubillas } \\
\text { Béznar }\end{array}$ & $\begin{array}{l}0.66^{b} \\
0.72^{b}\end{array}$ & $0.36^{\mathrm{NS}}$ \\
\hline & All data & $\begin{array}{l}\text { Cubillas } \\
\text { Béznar }\end{array}$ & $\begin{array}{l}0.68^{\mathrm{c}} \\
0.60^{\mathrm{b}}\end{array}$ & $0.45^{\mathrm{a}}$ \\
\hline$a_{320}$ & 2004 & $\begin{array}{l}\text { Cubillas } \\
\text { Béznar }\end{array}$ & $\begin{array}{r}0.72^{\mathrm{a}} \\
0.52^{\mathrm{NS}}\end{array}$ & $0.45^{\mathrm{NS}}$ \\
\hline
\end{tabular}

Correlations were significant at the ${ }^{\mathrm{a}} p<0.05$, $^{\mathrm{b}} p<0.001$ and ${ }^{\mathrm{c}} p<0.0001$ levels. NS, not significant.

and Béznar during 2004 and when all data were merged (Table 5). The absorption coefficients $a_{250}, a_{320}$ and $a_{440}$ were significantly higher in Cubillas and Béznar reservoirs than in Quéntar during 2004 and 2005 (Fig. 4, Table 4). Synchronous dynamics of the absorption coefficients at $320 \mathrm{~nm}$ were found only between Quéntar and Cubillas during 2005 (Table 5). The molar absorption coefficients were lower in Cubillas than in Quéntar and Béznar (Fig. 4, Table 4).

\subsection{Atmospheric WSOC contribution to dissolved organic matter and water transparency in the reservoirs}

We explored if DOC synchrony among the reservoirs could be related to the climate-driven atmospheric inputs of WSOC. We found significant and positive correlations between DOC concentrations and WSOC inputs in Cubillas $(n=38 ; r=0.42 ; p<0.05$; slope $=0.14 \pm 0.05)$ and in Quéntar $(n=44 ; r=0.39 ; p<0.05$; slope $=0.08 \pm 0.03)$ when 2004 and 2005 data were merged (Fig. 5). Cubillas is the reservoir with the highest ratio of surface area to mixing water depth, and Quéntar is the most oligotrophic reservoir (Table 1).

To evaluate whether atmospheric deposition provides substantial WSOC mass to influence directly DOC pool in each reservoir, we calculated the mass of WSOC loaded to the reservoirs during the stratification periods (Table 6). The mass of WSOC loaded during the whole stratification in 2004 and 2005 in the Quéntar reservoir was $11562 \mathrm{~mol}$ and $10622 \mathrm{~mol}$; in the Cubillas reservoir was $80934 \mathrm{~mol}$ and $70218 \mathrm{~mol}$ and in the Béznar reservoir $65236 \mathrm{~mol}$ and 47094 mol, respectively. Accordingly, WSOC loadings during the stratification periods of 2004 and 2005 accounted for $3.8 \%$ and $3.6 \%$ in Quéntar; $5.6 \%$ and $6.3 \%$ in Cubillas; and $2.7 \%$ and $2.5 \%$ in Béznar of the epilimnetic DOC mass.
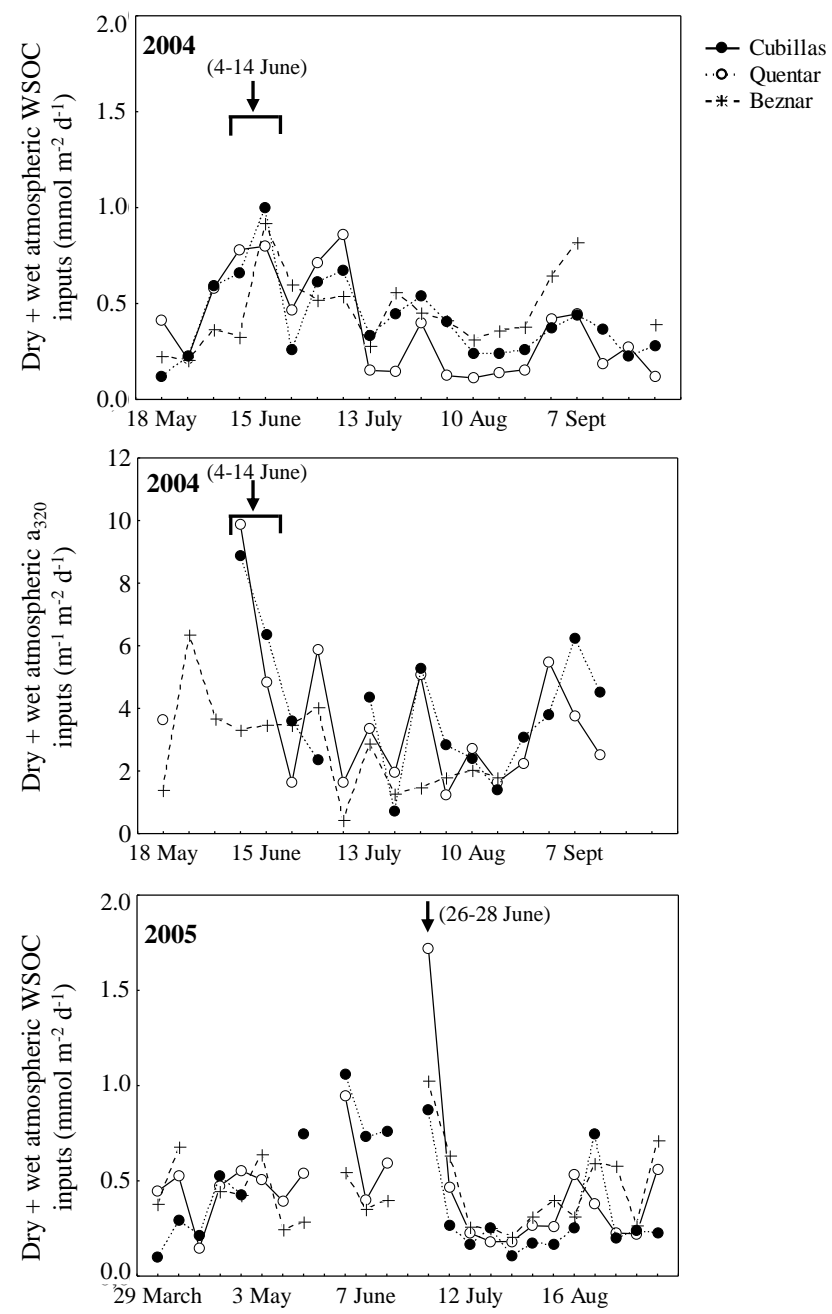

Fig. 2. Synchronous dynamics of water-soluble organic $\mathrm{C}$ (WSOC, mmol m $\mathrm{m}^{-2} \mathrm{~d}^{-1}$ ) and its absorption coefficient at $320 \mathrm{~nm}$ $\left(a_{320} \mathrm{~m}^{-1} \mathrm{~m}^{-2} \mathrm{~d}^{-1}\right)$ in the three collectors during the study periods of 2004 and 2005. The arrows point to relevant Saharan dust intrusions during the study periods (see also Fig. 3 for the aerosol index maps).

To explore the direct influence of the chromophoric components of WSOC on the UVR attenuation, we compared for each sampling day the depths where light intensity at $320 \mathrm{~nm}$ is reduced to ten percent of that at the surface $\left(z_{10} \%\right)$ for each reservoir (in situ conditions) and considering also the absorption provided by the chromophoric components of WSOC ( + dust conditions). Our results show that a highly significant $(p<0.0001)$ reduction in $z 10 \%$ occurred in all of the study reservoirs by the inputs of chromophoric components with the dust (Fig. 6). The average value of $z_{10} \%$ at $320 \mathrm{~nm}$ for the stratification period of 2004 decreased from $0.62 \mathrm{~m}$ to $0.13 \mathrm{~m}$ in Cubillas (ca. $79 \%$ ), from $0.59 \mathrm{~m}$ to $0.32 \mathrm{~m}$ in Béznar (ca. $45 \%$ ) and from 1.07 to $0.38 \mathrm{~m}$ in Quéntar (ca. $64 \%)$. 


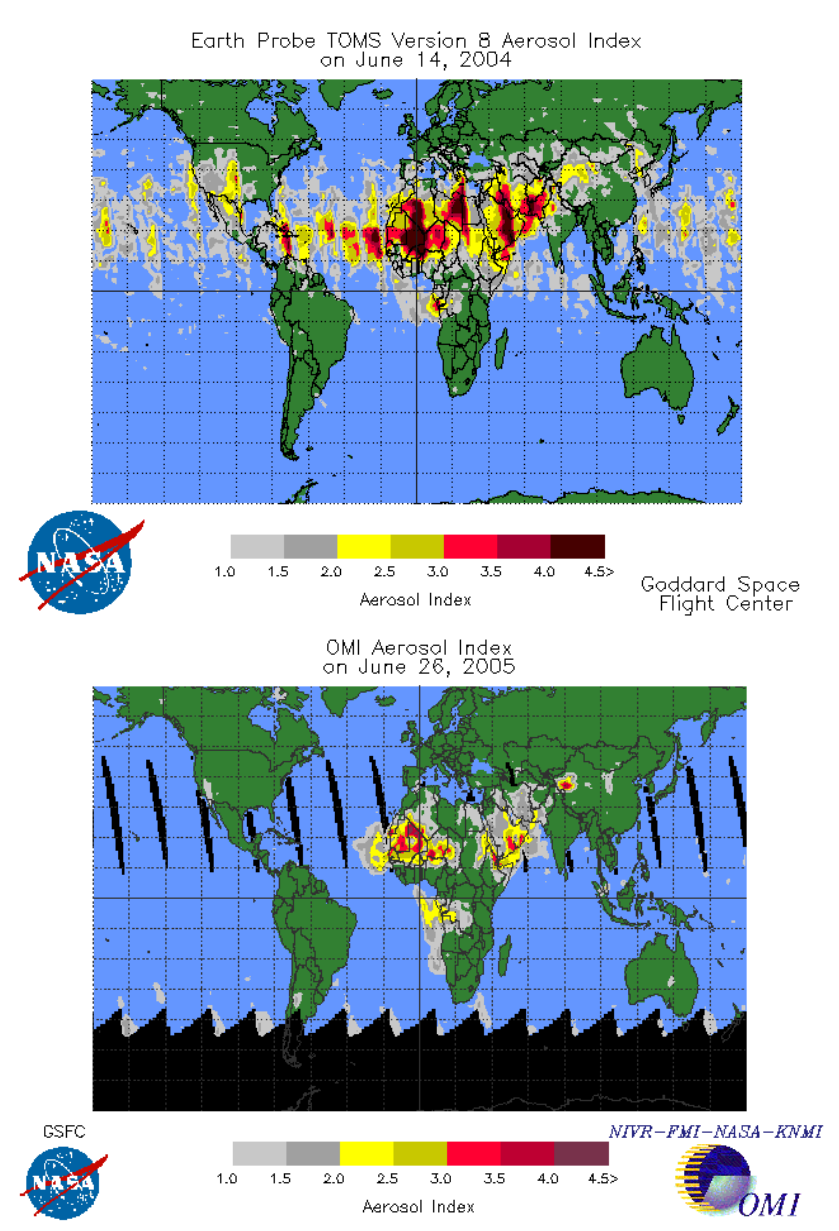

Fig. 3. Global maps of aerosol index provided by the spacecraft Earth Probe-Total Ozone Mapping Spectrometer (TOMS) for 14 June 2004 and Ozone Monitoring Instrument (OMI) for 26 June 2005 (http://disc.sci.gsfc.nasa.gov/giovanni/overview/ index.html). These dates correspond to relevant Saharan dust intrusions over the southeastern Iberian Peninsula where the atmospheric collectors were placed (see also Fig. 2 for the atmospheric deposition data).

\section{Discussion}

\subsection{Direct effects of WSOC deposition on the reservoir DOC and CDOM}

In the study reservoirs, DOC concentrations were similar to those reported in other Mediterranean reservoirs (Marcé et al., 2008), higher than in Asian temperate reservoirs (Kim et al., 2000; Wei et al., 2008) and lower than in European temperate reservoirs (Goslan et al., 2004; Pierson-Wickmann et al., 2010). Among the study reservoirs, the DOC concentration in Cubillas was always higher than in Béznar and Quéntar likely due to its highest catchment area and the ratio of catchment to reservoir area (Table 1). These last two parameters appear to be, at least in lake ecosystems, of major importance for determining the DOC concentration
(Xenopoulos et al., 2003; Sobek et al., 2007). In Cubillas reservoir also comparatively lower chromophoric organic matter content per $\mathrm{C}$ mole (i.e. $\varepsilon_{320}$ ) was observed (Fig. 4). This result could be a consequence of the differential influence of solar radiation on CDOM with respect to DOC. In fact, photomineralization (the loss of DOC due to sunlight) is a process much slower than photobleaching (the loss of CDOM due to sunlight) (Reche and Pace, 2002). Our hypothesis is that CDOM in Cubillas is submitted to more intense photobleaching than in the other two reservoirs because of its higher ionic strength (e.g. conductivity) and higher reservoir area to mixing depth ratio (Table 1). Indeed, the ionic strength and the morphometry of an aquatic ecosystem have significant effects on CDOM losses (Reche et al., 1999, 2000). The empirical relationship between the conductivity (the ionic strength of the solvent) and the CDOM photobleaching rates obtained by Reche et al. (1999) can be mechanistically explained by the gel-like properties of CDOM colloids as it has been recently explored by Pace et al. (2012). These last authors have demonstrated that the same CDOM appears in a more expanded (bigger hydrodynamic size) conformation with higher absorption capacity and photobleaching rates at alkaline $\mathrm{pH}$ than at acidic $\mathrm{pH}$. Therefore, irrespectively of CDOM nature, photobleaching rates are expected to be higher as the system is more alkaline.

In general, we found synchronous dynamics among the three study reservoirs for both DOC and CDOM (Table 5). The synchrony of a given parameter among spatially distant ecosystems is considered indicative of a significant (external) climatic control in the region (Baines et al., 2000). In temperate regions, environmental factors such as the precipitation or the incident radiation can affect both the DOC and CDOM dynamics and the synchrony among lakes (Curtis, 1998; Reche and Pace, 2002; Pace and Cole, 2002). In the Mediterranean region, however, the precipitation is very scant and, consequently, the runoff (enriched in chromophoric substances) inputs very limited. By contrast, this region is submitted to frequent Saharan dust intrusions mostly during spring and summer (Loye-Pilot et al., 1986; Bergametti et al., 1992; Moulin et al., 1997) when rain is almost absent. In fact, the maximum peaks of WSOC inputs were coincident with these Saharan dust events as it is shown in Fig. 3 corroborating its role as an external controlling factor. In fact, WSOC atmospheric inputs among all the collectors have also shown synchronous dynamics (Table 3) underlining a negligible contribution of the local dust sources.

The synchronous dynamics of DOC among the reservoirs and of WSOC among the collectors established significant correlations between the DOC concentrations and the atmospheric WSOC inputs in two out of the three reservoirs (Quéntar and Cubillas) (Fig. 5). The low DOC concentration in Quéntar and the high ratio of reservoir area to mixing depth in Cubillas make these two reservoirs particularly responsive to atmospheric dust inputs. Similarly, Mladenov et al. (2008) found that the relationship between the lake DOC 
Table 4. Average values and ranges (in parentheses) of dissolved organic carbon (DOC), absorption coefficients at $250 \mathrm{~nm}\left(a_{250}\right), 320 \mathrm{~nm}$ $\left(a_{320}\right)$, and $440 \mathrm{~nm}\left(a_{440}\right)$ in the study reservoirs during the stratification periods of 2004 and 2005.

\begin{tabular}{|c|c|c|c|c|c|c|c|c|}
\hline Year & Reservoirs & $\mathrm{DOC}(\mathrm{mM})$ & $a_{250}\left(\mathrm{~m}^{-1}\right)$ & $a_{320}\left(\mathrm{~m}^{-1}\right)$ & $a_{440}\left(\mathrm{~m}^{-1}\right)$ & $\varepsilon_{250}\left(\mathrm{~m}^{2} \mathrm{~mol}^{-1}\right)$ & $\varepsilon_{320}\left(\mathrm{~m}^{2} \mathrm{~mol}^{-1}\right)$ & $\varepsilon_{440}\left(\mathrm{~m}^{2} \mathrm{~mol}^{-1}\right)$ \\
\hline \multirow{3}{*}{2004} & Quéntar & $\begin{array}{c}0.16 \\
(0.06-0.35)\end{array}$ & $\begin{array}{c}5.80 \\
(3.10-8.04)\end{array}$ & $\begin{array}{c}1.69 \\
(0.56-2.29)\end{array}$ & $\begin{array}{c}0.42 \\
(0.01-0.85)\end{array}$ & $\begin{array}{c}41.0 \\
(18.0-93.8)\end{array}$ & $\begin{array}{c}12.0 \\
(3.6-24.0)\end{array}$ & $\begin{array}{c}2.9 \\
(0.1-5.6)\end{array}$ \\
\hline & Cubillas & $\begin{array}{c}0.36 \\
(0.20-0.57)\end{array}$ & $\begin{array}{c}10.39 \\
(7.75-13.23)\end{array}$ & $\begin{array}{c}2.69 \\
(1.60-3.84)\end{array}$ & $\begin{array}{c}0.53 \\
(0.22-0.77)\end{array}$ & $\begin{array}{c}31.92 \\
(20.82-50.49)\end{array}$ & $\begin{array}{c}8.49 \\
(3.72-16.26)\end{array}$ & $\begin{array}{c}1.68 \\
(0.53-3.71)\end{array}$ \\
\hline & Béznar & $\begin{array}{c}0.24 \\
(0.09-0.44)\end{array}$ & $\begin{array}{c}9.02 \\
(8.16-10.44)\end{array}$ & $\begin{array}{c}2.69 \\
(2.04-3.07)\end{array}$ & $\begin{array}{c}0.60 \\
(0.29-0.76)\end{array}$ & $\begin{array}{c}50.59 \\
(18.90-90.60)\end{array}$ & $\begin{array}{c}15.16 \\
(5.43-28.93)\end{array}$ & $\begin{array}{c}3.32 \\
(1.08-6.15)\end{array}$ \\
\hline \multirow{3}{*}{2005} & Quéntar & $\begin{array}{c}0.12 \\
(0.07-0.22)\end{array}$ & $\begin{array}{c}4.42 \\
(1.69-5.87) \\
\end{array}$ & $\begin{array}{c}1.17 \\
(0.27-2.11) \\
\end{array}$ & $\begin{array}{c}0.44 \\
(0.03-0.97) \\
\end{array}$ & $\begin{array}{c}42.67 \\
(11.92-82.66)\end{array}$ & $\begin{array}{c}11.88 \\
(3.84-29.76) \\
\end{array}$ & $\begin{array}{c}4.35 \\
(0.41-13.67) \\
\end{array}$ \\
\hline & Cubillas & $\begin{array}{c}0.34 \\
(0.22-0.51)\end{array}$ & $\begin{array}{c}9.40 \\
(6.41-11.64)\end{array}$ & $\begin{array}{c}2.59 \\
(0.77-4.01)\end{array}$ & $\begin{array}{c}0.83 \\
(0.25-1.80)\end{array}$ & $\begin{array}{c}29.37 \\
(14.37-47.59)\end{array}$ & $\begin{array}{c}7.81 \\
(1.74-12.19)\end{array}$ & $\begin{array}{c}2.38 \\
(0.64-4.53)\end{array}$ \\
\hline & Béznar & $\begin{array}{c}0.24 \\
(0.14-0.32)\end{array}$ & $\begin{array}{c}8.79 \\
(2.76-11.73)\end{array}$ & $\begin{array}{c}2.65 \\
(0.10-4.36)\end{array}$ & $\begin{array}{c}0.80 \\
(0.28-1.72)\end{array}$ & $\begin{array}{c}38.72 \\
(8.73-51.95)\end{array}$ & $\begin{array}{c}11.71 \\
(0.30-16.66)\end{array}$ & $\begin{array}{c}3.59 \\
(1.72-5.78)\end{array}$ \\
\hline
\end{tabular}
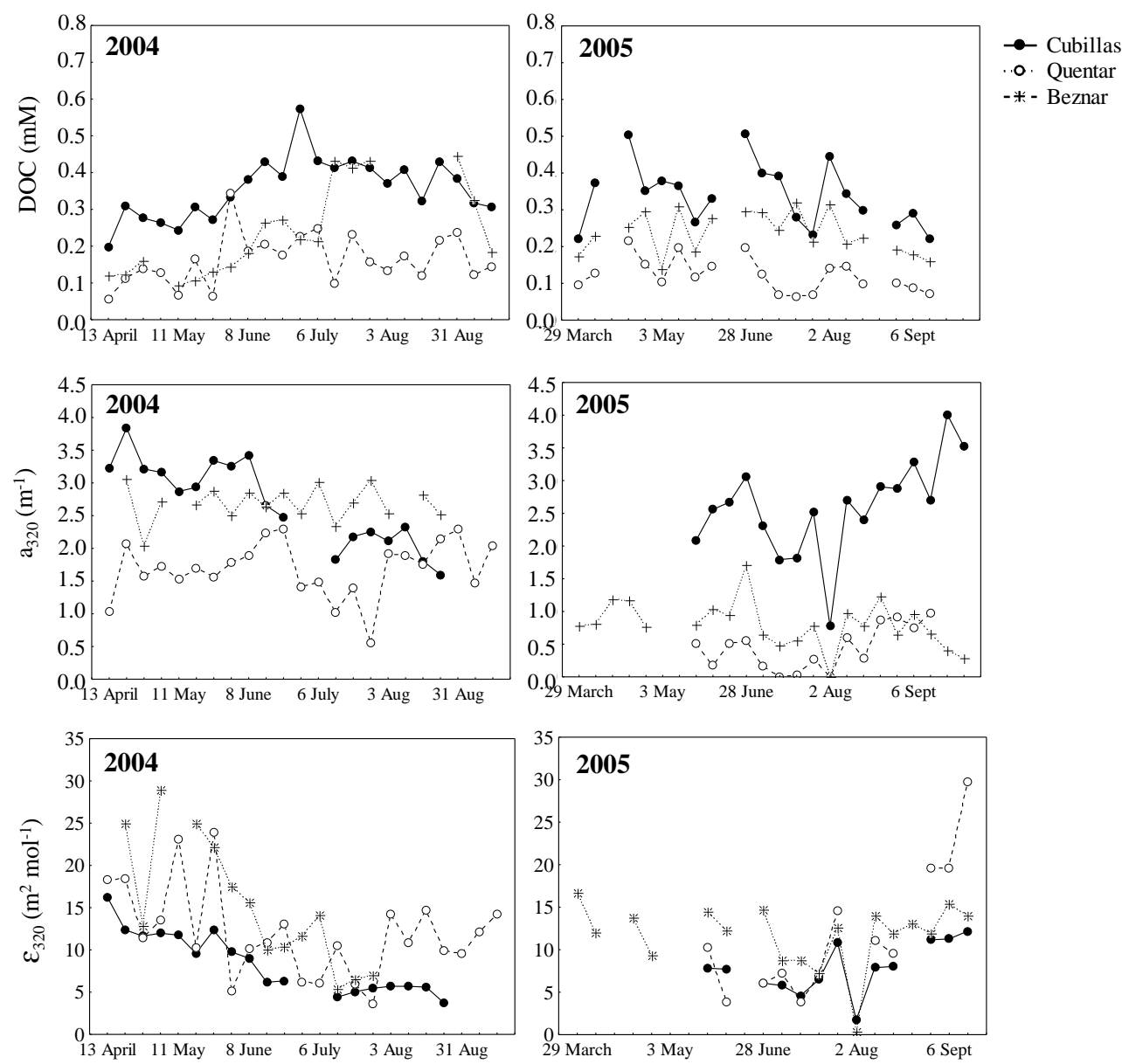

Fig. 4. Dynamics of dissolved organic carbon (DOC), absorption coefficients at $320 \mathrm{~nm}\left(a_{320}\right)$ and molar absorption coefficients at $320 \mathrm{~nm}$ $\left(\varepsilon_{320}\right)$ during the stratifications periods of 2004 and 2005 in the three study reservoirs. 
Table 5. Correlation coefficients between the different reservoirs for dissolved organic carbon (DOC) concentrations and absorption coefficients at $320 \mathrm{~nm}\left(a_{320}\right)$.

\begin{tabular}{|c|c|c|c|c|}
\hline & & & Quéntar & Cubillas \\
\hline \multirow{3}{*}{ DOC } & 2004 & $\begin{array}{l}\text { Cubillas } \\
\text { Béznar }\end{array}$ & $\begin{array}{r}0.60^{\mathrm{b}} \\
0.22^{\mathrm{NS}}\end{array}$ & $0.54^{\mathrm{a}}$ \\
\hline & 2005 & $\begin{array}{l}\text { Cubillas } \\
\text { Béznar }\end{array}$ & $\begin{array}{l}0.75^{\mathrm{c}} \\
0.47^{\mathrm{a}}\end{array}$ & $0.53^{\mathrm{a}}$ \\
\hline & All data & $\begin{array}{l}\text { Cubillas } \\
\text { Béznar }\end{array}$ & $\begin{array}{r}0.64^{\mathrm{c}} \\
0.268^{\mathrm{NS}}\end{array}$ & $0.50^{\mathrm{a}}$ \\
\hline \multirow{3}{*}{$a_{320}$} & 2004 & $\begin{array}{l}\text { Cubillas } \\
\text { Béznar }\end{array}$ & $\begin{array}{r}0.04^{\mathrm{NS}} \\
-0.36^{N S} \\
\end{array}$ & $-0.03^{N S}$ \\
\hline & 2005 & $\begin{array}{l}\text { Cubillas } \\
\text { Béznar }\end{array}$ & $\begin{array}{r}0.80^{\mathrm{b}} \\
-0.05^{\mathrm{NS}} \\
\end{array}$ & $-0.14^{\mathrm{NS}}$ \\
\hline & All data & $\begin{array}{l}\text { Cubillas } \\
\text { Béznar }\end{array}$ & $\begin{array}{r}0.38^{\mathrm{a}} \\
-0.07^{\mathrm{NS}}\end{array}$ & $0.05^{\mathrm{NS}}$ \\
\hline
\end{tabular}

Correlations were significant at the ${ }^{\mathrm{a}} p<0.05 ;{ }^{\mathrm{b}} p<0.001$ and

${ }^{\mathrm{c}} p<0.0001$ levels. NS, not significant.

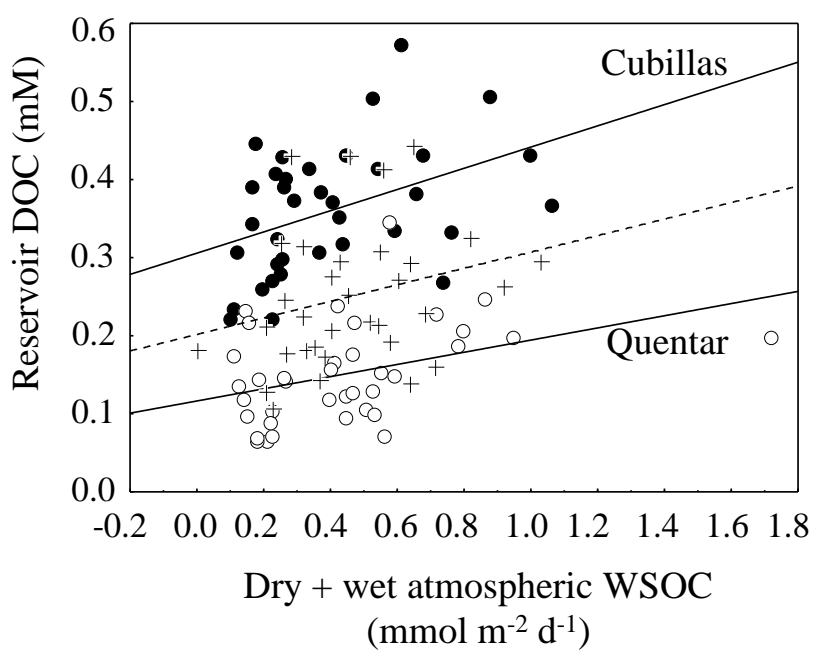

Fig. 5. Relationships between total (dry + wet) atmospheric WSOC inputs $\left(\mathrm{mmol} \mathrm{m}{ }^{-2} \mathrm{~d}^{-1}\right)$ and DOC concentrations $(\mathrm{mM})$ in the reservoirs merging data for both study years. Solid lines are shown for significant relationships $(p<0.05)$ in Cubillas (solid circles) and in Quéntar (empty circles).

reservoirs. The higher effect of chromophoric component inputs on light attenuation was observed, as expected, in the reservoir characterized by the most oligotrophic conditions (Quéntar) and in the reservoir with the smallest epilimnetic volume in relation to its surface area (Cubillas). These two features (oligotrophy and shallowness) are finally responsible for the lower dilution of the chromophoric components associated with the dust inputs in the reservoir waters being, therefore, more easily detectable.

The estimations of the mean residence time $\left(a_{320}\right.$ reservoir/a $a_{320}$ inputs) in the epilimnion of these chromophoric components provided by dust inputs ranged from 9.6 days in Quéntar to 23.1 days in Béznar. It is noteworthy that the residence times of the chromophoric components derived from atmospheric inputs are in terms of days, unlike the residence times of WSOC expressed in terms of years (Table 6).

The values of the residence time of the chromophoric compound inputs in the reservoirs are comparable to rough estimations of the losses due to photobleaching. In particular, if we estimate photobleaching losses in the study reservoirs using their conductivity values (Table 1), the equation proposed by Reche et al. (1999) (photobleaching rate $\left(\left(\mathrm{E} \mathrm{m}^{-2}\right)^{-1} \times 10^{-4}\right)=-15+8.9$ ln conductivity $)$ and the average measured daily incident sunlight $\left(61 \mathrm{E} \mathrm{m}^{-2} \mathrm{~d}^{-1}\right)$, and we express them in terms of half-life $(=\ln 0.5 /$ photobleaching rates; i.e. CDOM reduced to half of its initial conditions), the values range from 2.8 days in Cubillas to 3.2 days in Quéntar. Overall, the residence time of chromophoric inputs and the half-life by photobleaching in the reservoirs are in terms of a few days, whereas the residence times of atmospheric organic $\mathrm{C}$ inputs are in terms of years. 
Table 6. Contributions of water-soluble organic carbon (WSOC) inputs to mean dissolved organic carbon (DOC) pool into the epilimnion of the three study reservoirs and to the total DOC inputs (atmospheric + phytoplankton exudation) during the stratification period.

\begin{tabular}{|c|c|c|c|c|c|c|}
\hline \multirow{2}{*}{$\begin{array}{l}\text { Reservoir } \\
\text { Year }\end{array}$} & \multicolumn{2}{|c|}{ Quéntar } & \multicolumn{2}{|c|}{ Cubillas } & \multicolumn{2}{|c|}{ Béznar } \\
\hline & 2004 & 2005 & 2004 & 2005 & 2004 & 2005 \\
\hline $\begin{array}{l}\text { Epilimnetic DOC } \\
\text { pool (mol) }\end{array}$ & 301979 & 296787 & 1434127 & 1107836 & 2423874 & 1902893 \\
\hline $\begin{array}{l}\text { Atmospheric WSOC } \\
\text { inputs (mol) }\end{array}$ & 11562 & 10622 & 80934 & 70218 & 65236 & 47094 \\
\hline Residence time (yr) & 6.7 & 7.2 & 4.6 & 8.8 & 9.6 & 10.4 \\
\hline $\begin{array}{l}\text { Contribution of WSOC to } \\
\text { DOC pool }(\%)\end{array}$ & 3.8 & 3.6 & 5.6 & 6.3 & 2.7 & 2.5 \\
\hline $\begin{array}{l}\text { Estimations of DOC inputs } \\
\text { from phytoplankton } \\
\text { exudation (mol) }\end{array}$ & 93549 & & 2108444 & & 2500606 & \\
\hline $\begin{array}{l}\text { Contribution of WSOC to } \\
\text { DOC inputs during } \\
\text { stratification }(\%)\end{array}$ & 11 & & 3.7 & & 2.5 & \\
\hline
\end{tabular}

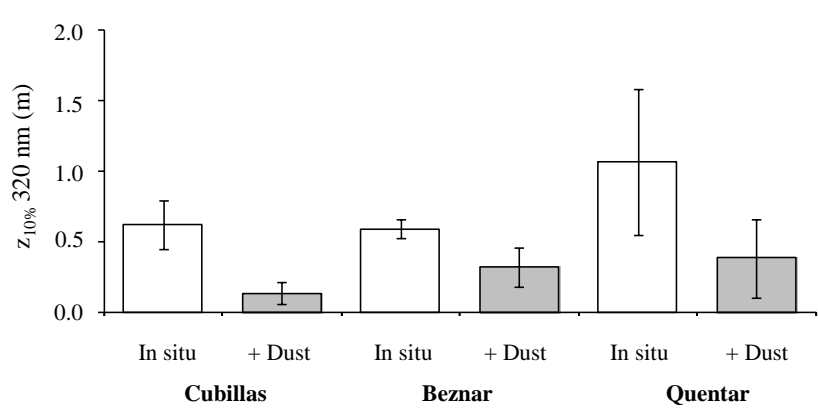

Fig. 6. Seasonal means (bars) and standard deviations (error bars) of the $Z_{10} \%$ values during the stratification period of 2004 considering the in situ conditions (white bars) and including the extra absorption due to the inputs of chromophoric components (gray bars). $Z_{10} \%$ values are the depths reached by the $10 \%$ of the surface incident radiation at $320 \mathrm{~nm}$ in the epilimnion of the study reservoirs.

The apparently contradictory results of the strong synchronies and correlations between WSOC inputs on DOC dynamics and the low quantitative contribution of WSOC inputs to the DOC pool could be explained to some extent by strong indirect effects that dust inputs also may produce in the reservoirs.

\subsection{Indirect effects of dust deposition on reservoir DOC and CDOM}

It is well understood that dust is a vector, besides organic $\mathrm{C}$, of mineral nutrients such as $\mathrm{P}, \mathrm{Fe}, \mathrm{Ca}, \mathrm{Mg}$ and $\mathrm{K}$ (Jickells et al., 2005; Pulido-Villena et al., 2006; Mahowald et al., 2008; Ballantyne et al., 2011). In the study region, a previous work by Morales-Baquero et al. (2006) reported that dry deposition was P-enriched and caused a significant increase of chlorophyll $a$ in two alpine lakes. Therefore, an expected stimulus of the primary producers by dust inputs could indirectly increase DOC pool via the exudation of DOC by phytoplankton (Baines and Pace, 1991). Hence, the additive effects of the direct WSOC inputs and the indirect DOC inputs derived from an increase in phytoplankton exudates could help to explain the synchronous patterns between WSOC inputs and DOC dynamics in two out of the three studied reservoirs. In fact, the only reservoir where we did not find a significant correlation between WSOC inputs and DOC concentrations was Béznar. This last reservoir has the lowest $N: P$ ratio, being the least $P$-limited (Table 1 ), and likely phytoplankton did not significantly respond to the $P$ inputs associated with dust.

In the Table 6, we compared the contribution of WSOC inputs to DOC pool with the estimation of the DOC inputs provided by phytoplankton exudation. We estimated primary productivity for each reservoir from chlorophyll- $a$ data (Smith, 1979), and we assumed an exudation rate of $13 \%$ of primary productivity (Baines and Pace, 1991). Whereas estimations of DOC derived from phytoplankton for the whole stratification period could be between $31 \%$ (Quéntar) and $147 \%$ (Cubillas) of the DOC pool, the WSOC inputs ranged from $2.5 \%$ (Béznar) to $11 \%$ (Quéntar). This comparison suggests a low to moderate contribution of atmospheric inputs to DOC pool being higher in the more oligotrophic reservoir. The importance of the degree of oligotrophy to detect the dust effects has been previously reported for marine ecosystems (Marañón et al., 2010).

On the other hand, the substantial direct effects of dust on water transparency could be even boosted since bacteria can be also significantly stimulated by dust inputs (PulidoVillena et al., 2008a, b; Reche et al., 2009). Bacteria, as a 
result of their own metabolism, also produce relevant quantities of chromophoric components (Ortega-Retuerta et al., 2009; Romera-Castillo et al., 2011). Therefore, a stimulus of bacterioplankton by dust inputs may also produce more CDOM. Indeed, Mladenov et al. $(2008,2011)$ found that dust and bacteria are the major factors controlling the optical properties of dissolved organic matter in oligotrophic high mountain lakes.

\section{Conclusions and environmental implications}

We obtained a low direct contribution of water-soluble organic carbon (WSOC) inputs to DOC pool with a residence time in terms of years in the epilimnion of the three study reservoirs. By contrast, the chromophoric components associated with the dust inputs affected significantly the water transparency to ultraviolet radiation with a residence time of the chromophoric components in terms of days in the epilimnion of the three study reservoirs.

The DOC synchrony among reservoirs and the significant correlations between WSOC inputs and DOC concentrations in two out of three reservoirs could be explained by a probable indirect contribution of phytoplankton exudates to DOC pool. The phosphorus associated with the dust may stimulate phytoplankton that release organic exudates promoting the synchrony between the $P$-limited reservoirs. The trophic status and the morphometry of the reservoir were key properties to detect the effects of dust inputs. We found that both the most oligotrophic and the most shallow of the three reservoirs included in this study were the most sensitive to dust inputs.

The WSOC and $a_{320}$ synchrony among the atmospheric collectors and the coincidence of their maximum inputs with important Saharan dust intrusions in the study area underline the role of dust exports as a relevant environmental factor for the aquatic ecosystems.

Currently, processes associated with global change, such as desertification and land use changes, are promoting an increase in dust exports to the atmosphere (Prospero and Lamb, 2003; Moulin and Chiapello, 2006; Mulitza et al., 2010). These increases of dust exports can have consequences for the aquatic ecosystems where the dust is deposited. Water transparency can be significantly reduced by dust deposition with consequences for the quality of freshwater resources as alpine lakes (Mladenov et al., 2011) as well as in reservoirs supplying drinking water to human population as it is shown in this work.

Acknowledgements. We thank O. Romera for valuable help in the field. This work was funded by the Spanish Ministry of Science and Technology (DISPAR, CGL2005-00076 to IR and CGL2008-06101/BOS to IdV) and by the Spanish Ministry of Education and Science (CICYT grant REN2003-03038 to RM-B).

Edited by: G. Herndl

\section{References}

Baines, S. B. and Pace, M. L.: The production of dissolved organic matter by phytoplankton and its importance to bacteria: Patterns across marine and freshwater systems, Limnol. Oceanogr., 36, 1078-1090, 1991.

Baines, S. B., Webster, K. E., Kratz, T. K., Carpenter, S. R., and Magnuson, J.: Synchronous behaviour of temperature, calcium and chlorophyll in lakes of northern Wisconsin, Ecology, 81, 815-825, 2000.

Ballantyne, A. P., Brahney, J., Fernandez, D., Lawrence, C. L., Saros, J., and Neff, J. C.: Biogeochemical response of alpine lakes to a recent increase in dust deposition in the Southwestern, US, Biogeosciences, 8, 2689-2706, doi:10.5194/bg-8-26892011, 2011.

Bergametti, G., Remoudaki, E., Losno, R., Steiner, E., Chatenet, B., and Buat-Menard, P.: Source, transport and deposition of atmospheric phosphorus over the northwestern Mediterranean, J. Atmos. Chem., 14, 501-513, 1992.

Bonnet, S., Guieu, C., Chiaverini, J., Ras, J., and Stock, A.: Effect of atmospheric nutrients on the autotrophic communities in a low nutrient, low chlorophyll system, Limnol. Oceanogr., 50, 1810 1819, doi:10.4319/lo.2005.50.6.1810, 2005.

Cole, J. J., Prairie, Y. T., Caraco, N. F., McDowell, W. H., Tranvik, L. J., Striegl, R. G., Duarte, C. M., Kortelainen, P., Downing, J. A., Middelburg, J. J., and Melack, J.: Plumbing the global carbon cycle: integrating inland waters into the terrestrial carbon budget, Ecosystems, 10, 171-184, 2007.

Curtis, P. J.: Climatic and hydrologic control on DOM concentration and quality in lakes, in: Aquatic Humic Substances, edited by: Hessen, T., 93-104, Springer-Verlag, Berlin, 1998.

Cory, R. M. and McKnight, D. M.: Fluorescence spectroscopy reveals ubiquitous presence of oxidized and reduced quinones in dissolved organic matter, Environ. Sci. Technol., 39, 8142-8149, 2005.

De Vicente, I., Rueda, F., Cruz-Pizarro, L., and Morales-Baquero, R.: Implications of seston settling on phosphorus dynamics in three reservoirs of contrasting trophic state, Fund. Appl. Limnol., 170, 263-272, 2008.

Downing, J. A., Prairie, Y. T., Cole, J. J., Duarte, C. M., Tranvik, L. J., Striegl, R. G., McDowell, W. H., Kortelainen, P., Caraco, N. F., Melack, J. M., and Middelburg, J. J.: The global abundance and size distribution of lakes, ponds and impoundments, Limnol. Oceanogr., 51, 2388-2397, 2006.

Goslan, E. H., Voros, S., Banks, J., Wilson, D., Hillis, P., Campbell, A. T., and Parsons, S. A.: A model for predicting dissolved organic carbon distribution in a reservoir water using fluorescence spectroscopy, Water Res., 38, 783-791, 2004.

Jickells, T. D., An, Z. S., Andersen, K. K., Baker, A. R., Bergametti, G., Brooks, N., Cao, J. J., Boyd, P. W., Duce, R. A., Hunter, K. A., Kawahata, H., Kubilay, N., la Roche, J., Liss, P. S., Mahowald, N., Prospero, J. M., Ridgwell, A. J., Tegen, I., and Torres, R.: Global Iron Connections Between Desert Dust, Ocean Biogeochemistry, and Climate, Science, 308, 67-71, 2005.

Kim, B., Choi, K., Kim, Ch., Lee, U. H., and Kim, Y. H.: Effects of the summer monsoon on the distribution and loading of organic carbon in a deep reservoir, lake Soyang, Korea, Water Res., 34, 3495-3504, 2000.

Loye-Pilot, M. D., Martin, J. M., and Morelli, J.: Influence of Saharan dust on the rain acidity and atmospheric input to the Mediter- 
ranean, Nature, 321, 427-428, 1986.

Mahowald, N., Benitez-Nelson, C. R., Bergametti, G., Bond, T. C., Chen, Y., Cohen, D. D., Herut, B., Kubilay, N., Losno, R., Luo, C., Maechaut, W., McGee, K. A., Okin, G. S., Siefert, R. L., and Tsukuda, S.: Global distribution of atmospheric phosphorus sources, concentrations and deposition rates and antrophogenic impacts, Global Biogeochem. Cy., 22, GB4026, doi:10.1029/2008GB003240, 2008.

Marañón, E., Fernández, A., Mouriño-Carballido, B., MartínezGarcía, S. Teira, E., Cermeño, P., Chouciño, P., Huete-Ortega, M., Fernández, E., Calvo-Díaz, A., Morán, X. A. G., Bode, A., Moreno-Ostos, E., Varela, M. M., Patey, M. D., and Achterbergf, E. P.: Degree of oligotrophy controls the response of microbial plankton to Saharan dust, Limnol. Oceanogr., 55, 2339-2352, 2010.

Marcé, R., Moreno-Ostos, E., and Armengol, J.: The role of allochthonous organic carbon on the hypolimnetic oxygen content of reservoirs, Ecosystems, 11, 1035-1053, 2008.

Mladenov, N., Pulido-Villena, E., Morales-Baquero, R., OrtegaRetuerta, E., Sommaruga, R., and Reche, I.: Spatiotemporal drivers of disolved organic matter in high alpine lakes: Role of Saharan dust inputs and bacterial activity, J. Geophys. Res., 113, G00D01, doi:10.1029/2008JG000699, 2008.

Mladenov, N., López-Ramos, J., McKnight, D. M., and Reche, I.: Alpine lake optical properties as sentinels of dust deposition and global change, Limnol. Oceanogr., 54, 2386-2400, 2009.

Mladenov, N., Sommaruga, R., Morales-Baquero, R., Laurion, I., Camarero, L., Diéguez, M. C., Camacho, A., Delgado, A., Torres, O., Chen, Z., Felip, M., and Reche, I.: Dust inputs and bacteria influence dissolved organic matter in clear alpine lakes, Nature Comms, 2, 405, doi:10.1038/ncomms1411, 2011.

Morales-Baquero, R., Conde-Porcuna, J. M., and Cruz-Pizarro, L.: The zooplankton biomass and food availability in four reservoirs of contrasting trophic status, Archiv. Hydrobiol., 40, 161-173, 1994.

Morales-Baquero, R., Pulido-Villena, E., and Reche I.: Atmospheric inputs of phosphorus and nitrogen to the southwest Mediterranean región: Biogeochemical responses of high mountain lakes, Limnol. Oceanogr., 51, 830-837, 2006.

Morris, D. P., Zagarese, H., Williamson, C. E., Balseiro, E. G., Hargreaves, B. R., Modenutti, B., Moeller, R., and Queimalinos, C.: The attenuation of solar UV radiation in lakes and the role of dissolved organic carbon, Limnol. Oceanogr., 40, 1381-1391, 1995.

Moulin, C. and Chiapello, I.: Impact of human-induced desertification on the intensification of Sahel dust emission and export over the last decades, Geophys. Res. Lett., 33, L18808, doi:10.1029/2006GL025923, 2006.

Moulin, C., Lambert, C. E., Dulac, F., and Dayan, U.: Control of atmospheric export of dust from North Africa by the North Atlantic Oscillation, Nature, 387, 691-694, 1997.

Mulitza, S., Heslop, D., Pittauerova, D., Fischer, H. W., Meyer, I., Stuut, J. B., Zabel, M., Mollenhauer, G., Collins, J. A., Kuhnert, H., and Schulz, M.: Increase in African dust flux at the onset of the commercial agriculture in the Sahel region, Nature, 466, 226-228, 2010.

Ortega-Retuerta, E., Frazer, T. K., Duarte, C. M., Ruiz-Halpern, S., Tovar-Sánchez, A., Arrieta, J. M., and Reche, I.: Biogeneration of chromophoric dissolved organic matter by bacteria and krill in the Southern Ocean, Limnol. Oceanogr., 54, 1941-1950, 2009.
Pace, M. L. and Cole, J. J.: Synchronous variation of dissolved organic carbon and color in lakes, Limnol. Oceanogr., 47, 333-342, 2002.

Pace, M. L., Reche, I., Cole, J. J., Fernandez-Barbero, A., Mazuecos, I. P., and Prairie, Y. T.: pH change induces shifts in the size and light absorption of dissolved organic matter, Biogeochemistry, 108, 109-118, doi:10.1007/s10533-011-9576-0, 2012.

Pérez-Martínez, C., Morales-Baquero, R., and Sánchez-Castillo, P.: The effect of the volume decreasing on the trophic status in four reservoirs from Southern Spain, Verhan. Internat. Verein Limnologie, 24, 1382-1385, 1991.

Pierson-Wickmann, A. C., Gruau, G., Jarde, E., Gaury, N., Brient, L., Lengronne, M., Crocq, A., Helle, D., and Lambert, T.: Development of a combined isotopic and massbalance approach to determine dissolved organic carbon sources in eutrophic reservoirs, Chemosphere, 83, 356-366, doi:10.1016/j.chemosphere.2010.12.014, 2010.

Prospero, J. M. and Lamb, P. J.: African droughts and dust transport to the Caribbean: climate change implications, Science, 302, 1024-1027, 2003.

Prospero, J. M., Ginoux, P., Torres, O., Nicholson, S. E., and Gill, T. E.: Environmental characterization of global sources of atmospheric soil dust identified with the NIMBUS 7 Total Ozone Mapping Spectrometer (TOMS) absorbing aerosol product, Rev. Geophys., 40, 1002, doi:10.1029/2000RG000095, 2002.

Pulido-Villena, E., Reche, I., and Morales-Baquero, R.: Significance of atmospheric inputs of calcium over the southwestern Mediterranean region: High mountain lakes as tools for detection, Global Biogeochem. Cy., 20, GB2012, doi:10.1029/2005GB002662, 2006

Pulido-Villena, E., Morales-Baquero, R., and Reche, I.: Evidence of an atmospheric forcing of bacterioplankton and phytoplankton dynamics in a high mountain lake, Aquat. Sci., 70, 1-9, 2008a.

Pulido-Villena, E., Wagener, T., and Guieu, C.: Bacterial response to dust pulses in the western Mediterranean: Implications for carbon cycling in the oligotrophic ocean, Global Biogeochem. Cy., 22, GB1020, doi:10.1029/2007GB003091, 2008b.

Reche, I. and Pace, M. L.: Linking dynamics of dissolved organic carbon in a forested lake with environmental factors, Biogeochemistry, 61, 21-36, 2002.

Reche, I., Pace, M. L., and Cole, J. J.: Relationship of trophic and chemical conditions to photobleaching of dissolved organic matter in lake ecosystems, Biogeochemistry, 44, 259-280, 1999.

Reche, I., Pace, M. L., and Cole, J. J.: Modeled effects of dissolved organic carbon and solar spectra on photobleaching in lake ecosystems, Ecosystems, 3, 419-432, 2000.

Reche, I., Ortega-Retuerta, E., Romera, O., Pulido-Villena, E., Morales-Baquero, R., and Casamayor, E. O.: Effect of Saharan dust inputs on bacterial activity and community composition in Mediterranean lakes and reservoirs, Limnol. Oceanogr., 54, 869879, 2009.

Romera-Castillo, C., Sarmento, H., Alvarez-Salgado, X. A., Gasol, J. M., and Marrase, C.: Net Production and Consumption of Fluorescent Colored Dissolved Organic Matter by Natural Bacterial Assemblages Growing on Marine Phytoplankton Exudates, Appl. Environ. Microbiol., 77, 490-7498, 2011.

Rueda, F. J., Fleenor, W. E., and de Vicente, I.: Pathways of river nutrients towards the euphotic zone in a deep- reservoir of small size: uncertainty analysis, Ecol. Model., 202, 345-361, 2007. 
Schütz, L., Jaenicke, R., and Pietrek, H.: Saharan dust transport over the North Atlantic Ocean, in: Dessert Dust, edited by: Péwé, T. L., 87-100, Spec. Pap. Geol. Soc. Am., 1981.

Smith, V. A.: Nutrient dependence of primary productivity in lakes, Limnol. Oceanogr., 24, 1051-1064, 1979.

Sobek, S., Tranvik, L., Prairie, Y. T., Kortelainen, P., and Cole, J. J.: Patterns and regulation of dissolved organic carbon: an analysis of 7500 widely distributed lakes, Limnol. Oceanogr., 52, 12081219, 2007.

StatSoft Inc.: Statistica for Windows (computer program manual), Tulsa, Oklahoma, USA, 1997.

Tipping, E., Hilton, J., and James, B.: Dissolved organic matter in Cumbrian lakes and streams, Freshwater Biol., 19, 371-378, 1988.

Tranvik, L. J., Downing, J. A., Cotner, J. B., Loiselle, S. A., Striegl, R. G., Ballatore, T. J., Dillon, P., Finlay, K., Fortino, K., Knoll, L. B., Kortelainen, P. L., Kutser, T., Larsen, S., Laurion, I., Leech, D. M., McCallister, S. L., McKnight, D. M., Melack, J. M., Overholt, E., Porter, J. A., Prairie, Y., Renwick, W. H., Roland, F., Sherman, B. S., Schindler, D. W., Sobek, S., Tremblay, A., Vanni, M. J., Verschoor, A. M., von Wachenfeldt, E., and Weyhenmeyer, G. A.: Lakes and impoundments as regulators of carbon cycling and climate, Limnol. Oceanogr., 54, 2298-2314, 2009.
Wei, Q. S., Feng, Ch. H., Wang, D. S., Shi, B. Y., Zhang, L. T., Wei, Q., and Tang, H. X.: Seasonal variations of chemical and physical characteristics of dissolved organic matter and trihalomethane precursors in a reservoir: a case study, J. Hazard. Mater., 150, 257-264, 2008.

Xenopoulos, M. A., Lodge, D. M., Frentress, J., Kreps, T. A., Bridgham, S. D., Grossman, E., and Jackson, C.: Regional comparisons of watershed determinants of dissolved organic carbon in temperate lakes from the Upper Great Lakes region and selected regions globally, Limnol. Oceanogr., 48, 2321-2334, 2003.

Yang, H., Li, Q. F., and Yu, J. Z.: Comparison of two methods for the determination of water-soluble organic carbon in atmospheric particles, Atmos. Environ., 37, 865-870, doi:10.1016/S13522310(02)00953-6, 2003. 